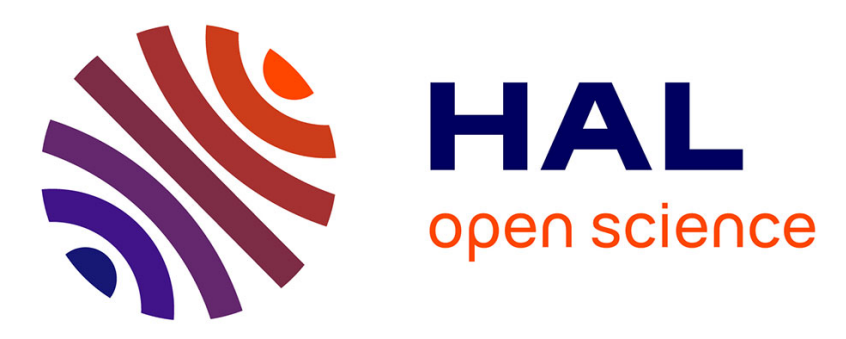

\title{
Variation in methanotroph-related proxies in peat deposits from Misten Bog, Hautes-Fagnes, Belgium
}

Julia F. van Winden, Helen M. Talbot, François de Vleeschouwer, Gert-Jan Reichart, Jaap S. Sinninghe Damsté

\section{- To cite this version:}

Julia F. van Winden, Helen M. Talbot, François de Vleeschouwer, Gert-Jan Reichart, Jaap S. Sinninghe Damsté. Variation in methanotroph-related proxies in peat deposits from Misten Bog, Hautes-Fagnes, Belgium. Organic Geochemistry, 2012, vol. 53, pp. 73-79. 10.1016/j.orggeochem.2012.07.001 . hal00984977

\section{HAL Id: hal-00984977 \\ https://hal.science/hal-00984977}

Submitted on 29 Apr 2014

HAL is a multi-disciplinary open access archive for the deposit and dissemination of scientific research documents, whether they are published or not. The documents may come from teaching and research institutions in France or abroad, or from public or private research centers.
L'archive ouverte pluridisciplinaire HAL, est destinée au dépôt et à la diffusion de documents scientifiques de niveau recherche, publiés ou non, émanant des établissements d'enseignement et de recherche français ou étrangers, des laboratoires publics ou privés. 


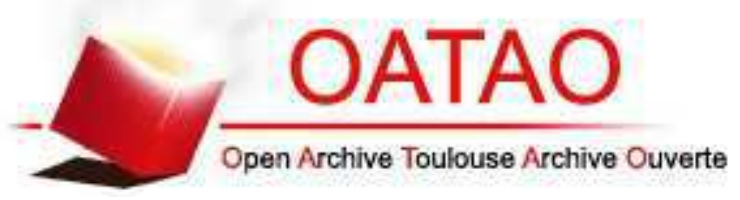

\section{Open Archive TOULOUSE Archive Ouverte (OATAO)}

OATAO is an open access repository that collects the work of Toulouse researchers and makes it freely available over the web where possible.

This is an author-deposited version published in : http://oatao.univ-toulouse.fr/ Eprints ID : 11487

To link to this article : doi:10.1016/j.orggeochem.2012.07.001

URL : http://dx.doi.org/10.1016/j.orggeochem.2012.07.001

To cite this version : van Winden, Julia F. and Talbot, Helen M. and De Vleeschouwer, François and Reichart, Gert-Jan and Sinninghe Damsté, Jaap S. Variation in methanotroph-related proxies in peat deposits from Misten Bog, Hautes-Fagnes, Belgium. (2012) Organic Geochemistry, vol. 53 . pp. 73-79. ISSN 0146-6380

Any correspondance concerning this service should be sent to the repository administrator: staff-oatao@ listes-diff.inp-toulouse.fr 


\title{
Variation in methanotroph-related proxies in peat deposits from Misten Bog, Hautes-Fagnes, Belgium
}

\author{
Julia F. van Winden ${ }^{a}$, Helen M. Talbot ${ }^{\mathrm{b}}$, François De Vleeschouwer ${ }^{\mathrm{c}, \mathrm{d}}$, Gert-Jan Reichart ${ }^{\mathrm{a}}$, \\ Jaap S. Sinninghe Damsté ${ }^{\mathrm{a}, \mathrm{e}, *}$ \\ ${ }^{a}$ Department of Earth Sciences, Utrecht University, P.O. Box 80.021, 3508 TA Utrecht, The Netherlands \\ ${ }^{\mathrm{b}}$ School of Civil Engineering and Geosciences, Newcastle University, Drummond Building, Newcastle Upon Tyne NE1 7RU, UK \\ ${ }^{\mathrm{c}}$ Université de Toulouse, INP, UPS, EcoLab (Laboratoire Ecologie Fonctionnelle et Environnement), ENSAT, Avenue de l'Agrobiopole, 31326 Castanet Tolosan, France \\ ${ }^{\mathrm{d}}$ CNRS, EcoLab, 31326 Castanet Tolosan, France \\ e Department of Marine Organic Biogeochemistry, NIOZ Royal Netherlands Institute for Sea Research, P.O. Box 59, 1790 AB Den Burg, The Netherlands
}

\begin{abstract}
A B S T R A C T
Methane emissions from peat bogs are strongly reduced by aerobic methane oxidising bacteria (methanotrophs) living in association with Sphagnum spp. Field studies and laboratory experiments have revealed that, with increasing water level and temperature, methanotrophic activity increases. To gain a better understanding of how longer term changes in methanotrophic activity are reflected in methanotroph biomarkers, a peat record $(0-100 \mathrm{~cm})$ from the Hautes-Fagnes (Belgium) encompassing the past 1500 years, was analysed for methanotroph-specific intact bacteriohopanepolyols (BHPs) and the carbon isotopic composition of diploptene. A predominance of aminobacteriohopanetetrol (aminotetrol) over aminobacteriohopanepentol (aminopentol) indicated the prevalence of type II methanotrophs. Relatively high methanotrophic activity was indicated by all methanotroph markers between 20 and $45 \mathrm{~cm}$ depth, around the present oxic-anoxic boundary, most likely representing the currently active methanotrophic community. Comparing methanotrophic markers in the deeper part of the peat profile with environmental variables afforded, however, no clear correlation between change in water level and methanotrophic activity. This is potentially caused by a predominance of type II methanotrophs, a combination of sources for methanotrophic biomarkers or insufficient variation in climatic changes. A proposed way forward would include a study of a core covering a longer timescale, thereby involving greater variability.
\end{abstract}

\section{Introduction}

Peat bogs are situated at mid to high latitude, primarily in the Northern Hemisphere, and play a large role in the global carbon cycle as they sequester a third of the Earth's soil carbon (Smith et al., 2004). They are also important in the global methane cycle, since they contribute approximately $10 \%$ of the total $\mathrm{CH}_{4}$ flux to the atmosphere (Gorham, 1991). Methane emission from peat bogs depends on a balance between archaeal methane production and subsequent bacterial methane oxidation. Aerobic methane oxidising bacteria (methanotrophs), living in association with Sphagnum spp., can retain up to $98 \%$ of the diffusive methane flux (van Winden et al., 2012a), but methane cycling strongly depends on environmental factors. Field studies and laboratory experiments have revealed that, with increasing water level and temperature, both methanogenic and methanotrophic activity increase (Frenzel and

* Corresponding author at: Department of Marine Organic Biogeochemistry, NIOZ Royal Netherlands Institute for Sea Research, P.O. Box 59, 1790 AB Den Burg, The Netherlands. Tel.: +31 222369550; fax: +31 222319674

E-mail address: damste@nioz.nl (J.S. Sinninghe Damsté).
Karofeld, 2000; Basiliko et al., 2004; McNamara et al., 2008; Larmola et al., 2010; Kip et al., 2010; van Winden et al., 2012a). Mesocosm experiments suggest, however, that methane oxidation is not able to keep up with increased production rate at increasing temperatures (van Winden et al., 2012a). However, such experiments cannot take into account long term adaptation of the microbial community. Hence, it remains unclear how methane cycling responds to changes in climate on longer timescales.

Insight into the adaptation on longer timescales can potentially be obtained by studying peat bog records when natural climate and environmental changes have resulted in differences in the extent of methane cycling. Variation in past methanotrophic activity is reflected in molecular proxies for methanotrophs (van Winden et al., 2012b), such as compound specific carbon isotopes of the bacterial marker diploptene, and methanotroph-specific intact bacteriohopanepolyols (BHPs, hopanoids with a polyfunctionalized side chain).

Methane is strongly depleted in ${ }^{13} \mathrm{C}$, yet diploptene, a lipid derived from methanotrophs (but also from other bacteria; e.g. Rohmer et al., 1984), exhibits only limited ${ }^{13} \mathrm{C}$ depletion, with $\delta^{13} \mathrm{C}$ 
values of ca. $-30 \%$ and $-40 \%$ in peat bogs (van Winden et al., 2010). This is probably the result of a mixed origin, since methanotrophs are not the only bacterial source for diploptene. Furthermore, serine cycle methanotrophs (type II), which form part of the methanotrophic community, do not only use methane but also $\mathrm{CO}_{2}$ as carbon source, thereby diluting the ${ }^{13} \mathrm{C}$ depleted, methanederived signal in methanotroph lipids. Nevertheless, in a previous mesocosm experiment, it was shown that the carbon isotopic depletion of diploptene strongly correlated with methane production and methane consumption (van Winden et al., unpublished data). This may be a result of an increased contribution of methanotroph-derived diploptene with enhanced methane cycling. Alternatively, it is possibly caused by enhanced expression of the enzymatic isotope effect associated with methane oxidation, with increased methane availability.

Methanotroph-specific BHPs may also serve as biomarkers for methanotrophy, potentially containing useful process-specific information.

Methanotrophs in peat bogs comprise two main groups, type I methanotrophs ( $\gamma$-Proteobacteria) and type II methanotrophs $(\alpha-$ Proteobacteria). Aminobacteriohopanepentol (aminopentol) is a marker for type I methanotrophs, while aminobacteriohopanetetrol (aminotetrol) is indicative for type II methanotrophs (Neunlist and Rohmer, 1985a,b; Cvejic et al., 2000; Talbot et al., 2001; Coolen et al., 2008; van Winden et al., 2012b). Still, the latter may also be produced to a lesser extent by type I methanotrophs and some sulfate reducing bacteria (Neunlist and Rohmer, 1985a; Cvejic et al., 2000; Talbot et al., 2001; Blumenberg et al., 2006, 2009a,b; van Winden et al., 2012b). Methylocella-like methanotrophs, belonging to the Beijerinckiaceae family within the type II methanotrophs, have been speculated to be one of the most important methane oxidisers in peat bogs (Dedysh, 2009). They are not closely related to the other type II methanotrophs. The only Methylocella-like methanotroph analysed for BHPs did not contain aminotetrol, but mainly aminobacteriohopanetriol (aminotriol) and bacteriohopanetetrol (BHT), which are also produced by many other bacteria (van Winden et al., 2012b). BHPs can thus be used to trace contributions of methanotrophs in peat records but the results require careful interpretation.

To gain a better understanding on how longer term climatic and environmental changes affected methanotrophic activity, a peat record from the Hautes-Fagnes, Belgium, encompassing the past
1500 years, was investigated. The core was recovered from the edge of a hummock, to ensure maximum sensitivity to changes in hydrology (De Vleeschouwer et al., 2012). It was analysed for methanotropic biomarkers including intact bacteriohopanepolyols (BHPs) and for compound specific carbon isotope values of diploptene.

\section{Experimental}

\subsection{Site description}

The peat monolith was obtained using a plain titanium $15 \times 15 \times 100 \mathrm{~cm}$ Wardenaar corer (Wardenaar, 1986) in February 2008 from Misten Bog, Hautes-Fagnes, East Belgium (50³3'50"N, $06^{\circ} 09^{\prime} 50^{\prime \prime} \mathrm{E}$; Fig. 1) and has been described in detail elsewhere (De Vleeschouwer et al., 2012 and references therein). Briefly, the bog is ombrotrophic in nature and present day average precipitation rate is $1440 \mathrm{~mm} / \mathrm{yr}$ at a mean annual air temperature of $6.7^{\circ} \mathrm{C}$. Currently, the surface Sphagnum hummocks and lawns are covered with abundant shrubs such as Erica tetralix, Calluna vulgaris and Vaccinium spp., reflecting the ongoing evolution of the bog into a peat moor. At the coring site, some Ericales rootlets extended up to ca. $30 \mathrm{~cm}$ depth.

\subsection{Dating and age model}

The methods used to establish the chronology of the core are derived from and reported in De Vleeschouwer et al. (2012). Briefly, the dates for the peat horizons were based on ${ }^{14} \mathrm{C}$ AMS dates of selected plant macrofossils, as reported by De Vleeschouwer et al. (2012). ${ }^{210} \mathrm{~Pb}$ was also used to date the most recent layers (down to $18 \mathrm{~cm}$ ) and an age model for ${ }^{210} \mathrm{~Pb}$ derived according to the Constant Rate of Supply (CRS) model (Appleby, 2001). An age model was constructed using the ${ }^{14} \mathrm{C}$ dates and the modelled ${ }^{210} \mathrm{~Pb}$ ages. Radiocarbon dates were translated to calendar ages using the IntCal09 calibration curve (Reimer et al., 2009).

\subsection{Extraction and derivatisation}

The monolith was sliced in to ca. $1 \mathrm{~cm}$ sections. Fourteen slices were selected from the $1 \mathrm{~m}$ profile (see Table 1 for detailed

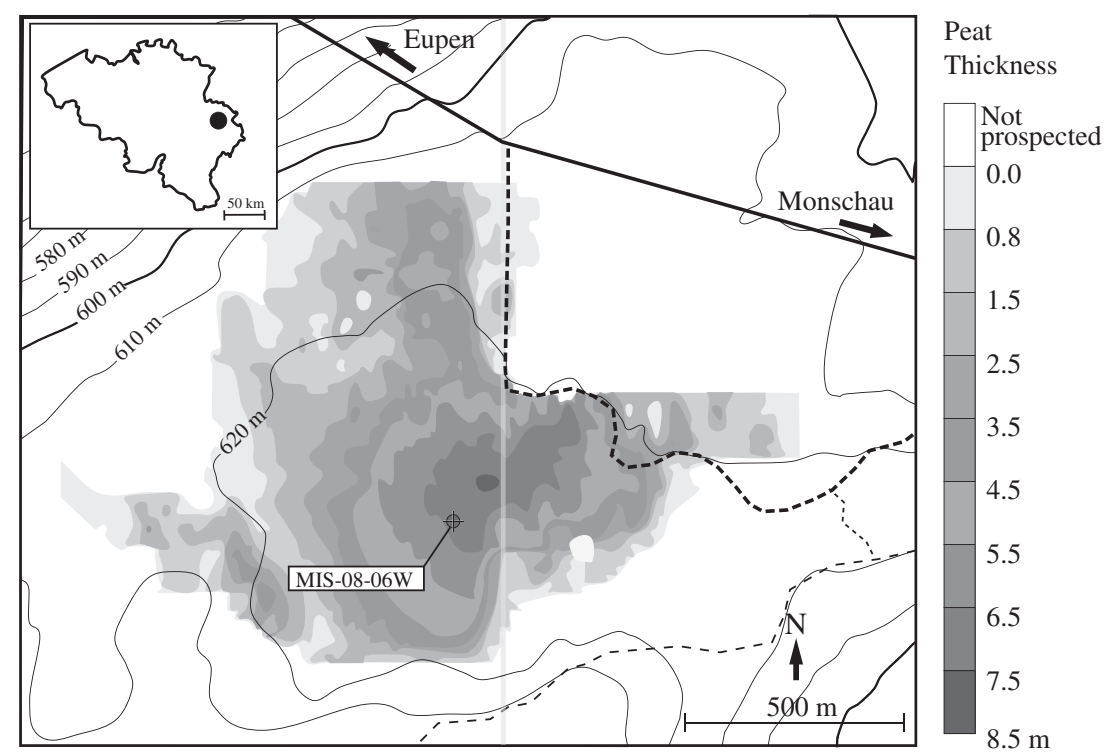

Fig. 1. Misten Bog and core location (MIS-08-06W), after De Vleeschouwer et al. (2012). 
Table 1

Concentrations of BHPs ( $\mu \mathrm{g} \mathrm{g}^{-1}$ dry sediment), quantified using HPLC-MS (accuracy $\pm 20 \%$ ). at various depths in the peat core.

\begin{tabular}{|c|c|c|c|c|c|c|c|c|c|c|c|c|}
\hline $\begin{array}{l}\text { Depth } \\
(\mathrm{cm})\end{array}$ & BHT & 2-MethylBHT & Aminotetrol & Aminopentol & Aminotriol & Adenosylhopane & $\begin{array}{l}\text { BHT } \\
\text { cyclitol } \\
\text { ether }\end{array}$ & $\begin{array}{l}\text { BHT } \\
\text { glucosamine }\end{array}$ & $\begin{array}{l}\text { 2-MethylBHT } \\
\text { cyclitol ether }\end{array}$ & $\begin{array}{l}\text { BHpentol } \\
\text { cyclitol ether }\end{array}$ & $\begin{array}{l}\text { BHhexol } \\
\text { cyclitol } \\
\text { ether }\end{array}$ & Total \\
\hline 13.7 & 45 & 26 & 8 & 0 & 295 & 88 & 215 & 8 & 12 & 6 & 12 & 715 \\
\hline 21.5 & 74 & 21 & 13 & 4 & 366 & 92 & 400 & 10 & 12 & 6 & 8 & 1007 \\
\hline 30.7 & 80 & 14 & 22 & 5 & 393 & 94 & 403 & 9 & 34 & 11 & 11 & 1076 \\
\hline 43.4 & 97 & 15 & 35 & 4 & 414 & 65 & 421 & 13 & 26 & 9 & 9 & 1107 \\
\hline 50.5 & 89 & 22 & 15 & 1 & 310 & 81 & 379 & 8 & 27 & 4 & 3 & 939 \\
\hline 58.5 & 96 & 15 & 10 & 3 & 372 & 42 & 359 & 12 & 19 & 7 & 2 & 938 \\
\hline 60.9 & 81 & 13 & 12 & 3 & 413 & 52 & 337 & 7 & 19 & 6 & 3 & 945 \\
\hline 63.5 & 89 & 18 & 10 & 2 & 454 & 61 & 502 & 5 & 37 & 7 & 5 & 1190 \\
\hline 69.8 & 161 & 19 & 20 & 3 & 711 & 68 & 511 & 11 & 32 & 9 & 12 & 1558 \\
\hline 79.7 & 98 & 21 & 14 & 3 & 432 & 46 & 195 & 9 & 14 & 3 & 3 & 837 \\
\hline 86.8 & 81 & 16 & 6 & 1 & 497 & 32 & 317 & 5 & 27 & 6 & 2 & 990 \\
\hline 93.7 & 81 & 9 & 6 & 3 & 388 & 34 & 348 & 5 & 21 & 2 & 3 & 898 \\
\hline 96.4 & 76 & 12 & 7 & 2 & 323 & 33 & 314 & 5 & 24 & 5 & 5 & 808 \\
\hline 99.4 & 61 & 16 & 9 & 2 & 351 & 36 & 441 & 4 & 27 & 5 & 2 & 956 \\
\hline
\end{tabular}

depths), freeze-dried and extracted using a modified Bligh and Dyer procedure (Cooke et al., 2008). An aliquot of the extract was used for hopene analysis and separated into an apolar and a polar fraction over an activated $\mathrm{Al}_{2} \mathrm{O}_{3}$ column using hexane:dichloromethane (DCM; 9:1 v/v) and DCM:MeOH (1:1 v/v). To separate hopenes from acyclic and saturated hydrocarbons, the apolar fraction was eluted over an $\mathrm{AgNO}_{3}$-impregnated column using $\mathrm{DCM}$, after elution with hexane, hexane:DCM (9:1), hexane:DCM (1:1) and DCM. The DCM fraction was dried, dissolved in hexane and analysed using gas chromatography (GC), GC-mass spectrometry (GC-MS) and GC-isotope ratio monitoring mass spectrometry (GC-IRMS).

Another aliquot of the extract was used for BHP analysis. After addition of the internal standard ( $5 \alpha$-pregnane-3 $\beta, 20 \beta$-diol) the aliquot was acetylated with $\mathrm{Ac}_{2} \mathrm{O}$ and pyridine $\left(1: 1 \mathrm{v} / \mathrm{v} ; 50^{\circ} \mathrm{C}\right.$, $1 \mathrm{~h}$ ) and left to stand at room temperature overnight. The acetylated extract was dried at $50{ }^{\circ} \mathrm{C}$ under a continuous $\mathrm{N}_{2}$ flow. After filtration with a $0.45 \mu \mathrm{m}$ PTFE syringe filter, the extract was dissolved in $\mathrm{MeOH} /$ propan-2-ol (60:40 v/v), prior to high performance liquid chromatography (HPLC) MS.

\subsection{GC, GC-MS and GC-IRMS}

GC was performed with a HP 6890 gas chromatograph equipped with flame ionisation detection (FID) set at constant pressure $(100 \mathrm{kPa})$. A fused silica column $(30 \mathrm{~m} \times 0.32 \mathrm{~mm}$ i.d., film thickness $0.1 \mu \mathrm{m}$ ) coated with CP Sil-5CB was used with He as carrier gas. Samples were injected on-column at $70^{\circ} \mathrm{C}$ and temperature was increased at $20^{\circ} \mathrm{C}$ per min to $130{ }^{\circ} \mathrm{C}$ and $4{ }^{\circ} \mathrm{C} \mathrm{min}{ }^{-1}$ to $320^{\circ} \mathrm{C}$ (held $20 \mathrm{~min}$ ). Quantification was performed by integration of peak areas, using squalane as a co-injected internal standard.

Components were identified using a Thermo Trace GC Ultra (equipped with the same type of column and using the same temperature programme as for GC) coupled to a Finnigan Trace DSQ Single Quadrupole mass spectrometer (GC-MS).

Compound specific $\delta^{13} \mathrm{C}$ values were determined using GCIRMS; ThermoFisher Delta V; with the same type of column and using the same GC temperature programme as above. Carbon isotopic $(\delta)$ values are reported relative to the Vienna Peedee Belemnite (VPDB) standard, with a reproducibility of, on average, $0.5 \%$.

\subsection{HPLC-(atmospheric chemical ionisation (APCI)-MS}

Reversed-phase HPLC analysis was carried out using a Surveyor HPLC system (ThermoFinnigan, Hemel Hempstead, UK) fitted with a Gemini (Phenomenex, [Macclesfield, UK] $\mathrm{C}_{18} 5 \mu \mathrm{m}$ column
$(150 \mathrm{~mm} \times 3.0 \mathrm{~mm}$ i.d.) and a security guard column of the same material. Separation was achieved at a flow rate of $0.5 \mathrm{ml} / \mathrm{min}$ at $30{ }^{\circ} \mathrm{C}$ with the following gradient profile: $90 \% \mathrm{~A}$ and $10 \% \mathrm{~B}$ (0 min); 59\% A, 1\% B and 40\% C (at $25 \mathrm{~min}$ ), then isocratic (to $40 \mathrm{~min}$ ) and returning to the starting conditions over $5 \mathrm{~min}$ and finally stabilizing for $15 \mathrm{~min}$ before the next injection $(\mathrm{A}=\mathrm{MeOH}$, $\mathrm{B}=$ water and $\mathrm{C}=$ propan-2-ol; all Fisher Scientific HPLC grade). HPLC-MS was performed using a ThermoFinnigan LCQ ion trap mass spectrometer equipped with an APCI source operated in positive ion mode. Analysis was carried out in data-dependent mode with three scan events: SCAN 1 - full mass spectrum $(\mathrm{m} / \mathrm{z} 300$ 1300); SCAN 2 - data-dependent $M^{2}$ spectrum of most abundant ion from SCAN 1; SCAN 3 - data-dependent MS $^{3}$ spectrum of most abundant ion from SCAN 2.

A semi-quantitative estimate of concentration was obtained based on the comparison of response factors of five authentic peracetylated BHP standards (provided by M. Rohmer, Strasbourg, France; Cooke et al., 2008) relative to the internal standard $5 \alpha$ pregnane-3 $\beta, 20 \beta$-diol. Bacteriohopanetetrol (BHT) was the only available standard which does not contain $\mathrm{N}$ and gives a response $8 \times$ that of the internal standard. Four N-containing BHPs, i.e. 3 tetrafunctionalized composite structures (aminotriol; BHT cyclitol ether VI and the related BHT glucosamine IX) and adenosylhopane $(\mathrm{V})$ were available. Although these $4 \mathrm{~N}$-containing BHPs individually show some slight variation in response factor over time, taken as an average the response factor remains consistent at $12 \times$ that of the internal standard (van Winden et al., 2012b). As only a limited number of standards were available relative to the known variety of possible structures, this average value was used for all N-containing BHPs including penta- and hexafunctionalised structures for which no standards were available. Quantification was performed using $\mathrm{m} / \mathrm{z}$ traces targeting the characteristic base peak, i.e. $[\mathrm{M}+\mathrm{H}]^{+}$, ion for $\mathrm{N}$-containing structures and $\left[\mathrm{M}+\mathrm{H}-\mathrm{CH}_{3} \mathrm{COOH}\right]^{+}$for those with no $\mathrm{N}$ relative to the base peak ion of the internal standard $\left(m / z \quad 345=\left[\mathrm{M}+\mathrm{H}-\mathrm{CH}_{3} \mathrm{COOH}\right]^{+}\right)$. Reproducibility was $\pm 20 \%$ based on replicate injections of a range of samples on different days over time (Cooke, 2010) and was comparable to that reported by other workers (Blumenberg et al., 2009a,b).

\section{Results and discussion}

\subsection{BHPs as markers for methanotrophs}

BHPs detected across the peat profile include BHT, aminotriol, aminotetrol and aminopentol (Fig. 2b-e), known to be produced 


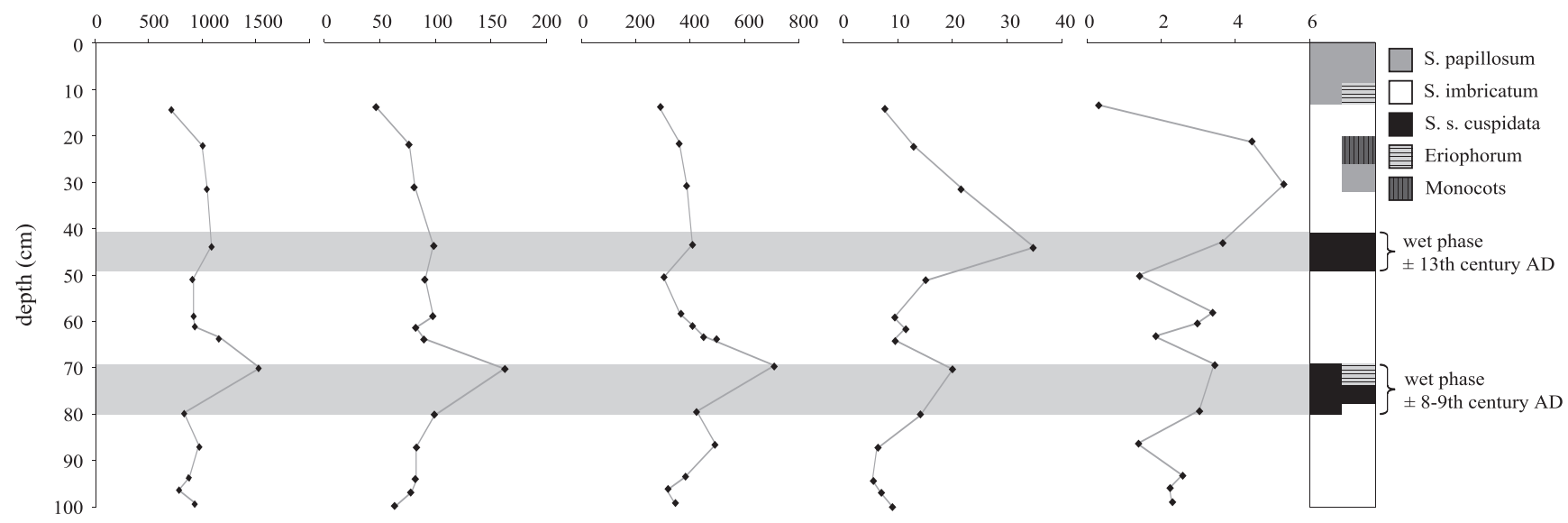

(f) Diploptene ( $\mu \mathrm{g} / \mathrm{g}) \quad$ (g) Hop-17(21)-ene ( $\mu \mathrm{g} / \mathrm{g})(\mathrm{h}) \delta^{13} \mathrm{C}$ Diploptene (\%o)

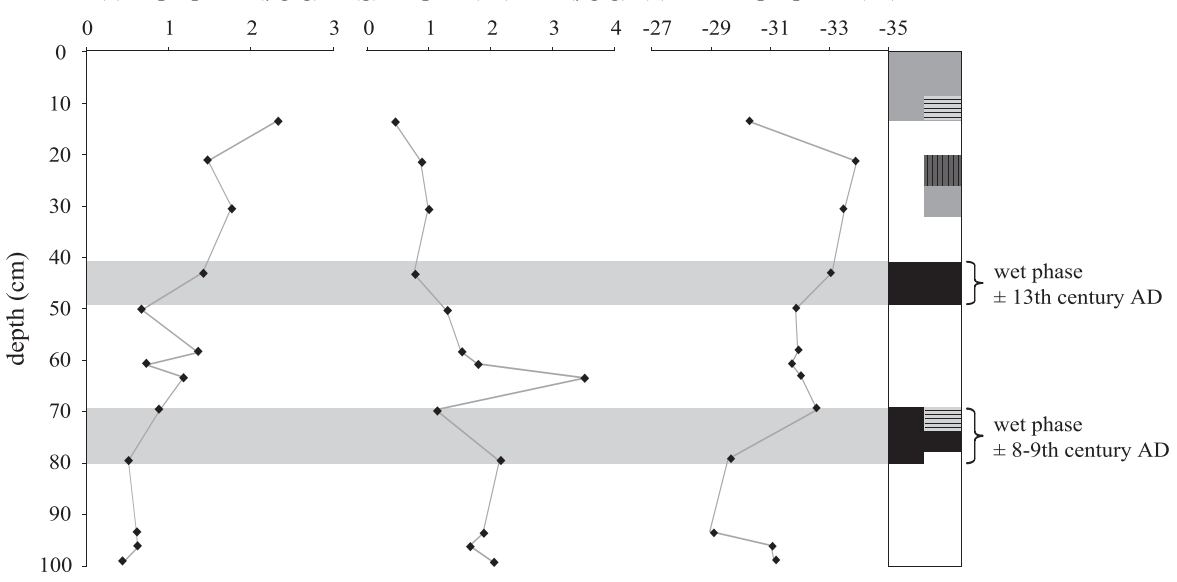

Fig. 2. Depth distribution of (a) BHPs total, (b) BHT, (c) aminotriol, (d) aminotetrol, (e) aminopentol, (f) diploptene, (g) hop-17(21)-ene and (h) diploptene $\delta^{13} \mathrm{C}(\%)$ in a $100 \mathrm{~cm}$ peat core from Misten Bog, Hautes-Fagnes, Belgium. On the left axis, the current catotelm-acrotelm boundary is indicated and on the right axis, an abstracted vegetation profile is shown, along with the approximate dates of the wet phases (dominated by S. s. Cuspidata), adapted from De Vleeschouwer et al. (2012).

by methanotrophs (Rohmer et al., 1984; Neunlist and Rohmer, 1985a,b; Cvejic et al., 2000; Talbot et al., 2001; Coolen et al., 2008; van Winden et al., 2012b). Other BHPs present throughout the profile are 2-methylBHT, adenosylhopane, BHT cyclitol ether, BHT glucosamine, 2-methylBHT cyclitol ether, BHpentol cyclitol ether and BHhexol cyclitol ether (Table 1). Aminotriol and BHT cyclitol ether are the most abundant BHPs in all the samples. The depth distribution of the summed BHP concentration is rather constant, with only elevated values around $70 \mathrm{~cm}$ (Fig. 2a). The concentration profiles of BHT and aminotriol closely resemble that of the summed BHPs (Fig. 2b, c and a, respectively). The concentrations of aminotetrol and aminopentol are lower than BHT and aminotriol and both show some variability with depth, with peaks in abundance between 20 and $45 \mathrm{~cm}$ and at around $70 \mathrm{~cm}$ (Fig. 2d and e). High aminotetrol and aminopentol abundances between 20 and $45 \mathrm{~cm}$ suggest enhanced methanotrophic activity (Fig. 2d and e). The present oxic-anoxic interface starts around $25 \mathrm{~cm}$ (De Vleeschouwer et al., 2012). Since methanotrophic activity is typically highest around the oxic-anoxic interface (Basiliko et al., 2004; van Winden et al., 2012a), the high aminotetrol and aminopentol concentrations between 20 and $45 \mathrm{~cm}$ probably reflect ongoing methanotrophic activity.

The presence of aminopentol confirms the presence of type I methanotrophs, yet the abundance of aminotetrol is significantly higher than it (Fig. 2d and e). This indicates a prevalence of type II methanotrophs. Kip et al. (2011) identified two main types of methanotroph, a type II Methylocystus sp. and a type I Methylomonas sp. as the dominating methanotrophs in several Sphagnum ecosystems. These groups produce primarily aminotetrol and aminopentol, respectively (Talbot et al., 2001; van Winden et al., 2012b), so our results are therefore largely in line with the study of Kip et al. (2011).

The peak abundance in aminopentol is at shallower depth vs. that of aminotetrol (Fig. 2d and e), similar to the pattern observed in another active peat bog (van Winden et al., 2012b). The difference in depth for the peak abundances in the top part of the peat core possibly suggests a slight difference in oxygen and methane affinity between type I and type II methanotrophs, as observed by Crossman et al. (2004). Type I methanotrophs are situated at shallower depth, where oxygen concentration is higher and methane level lower, while type II methanotrophs prefer lower oxygen concentration and higher methane concentration (Crossman et al., 2004).

In the topmost sample, at $14 \mathrm{~cm}$, aminopentol is below detection limit and aminotetrol concentration is low (Fig. $2 \mathrm{~d}$ and e), in line with low methanotrophic activity. As the top $14 \mathrm{~cm}$ of the peat are well above the oxic-anoxic interface, methanotrophic activity should be limited.

Methanotrophs may also produce BHT and aminotriol, which are, however, less diagnostic as they are also rather common among other bacteria (e.g. Talbot et al., 2008). Methylocella-like methanotrophs, hypothesised to be one of the most important 
methanotrophs in peat bogs (Dedysh, 2009) do not, to the best of our knowledge, produce the diagnostic aminotetrol and amonopentol, but primarily aminotriol (van Winden et al., 2012b; Talbot et al., unpublished data). In the core, BHT and aminotriol largely reflect the pattern of the cumulative BHPs, albeit that levels are slightly elevated between 20 and $45 \mathrm{~cm}$ (Fig. 2a-c). Except for the peak abundance at $70 \mathrm{~cm}$, they do not match the curve of aminotetrol or aminopentol. BHT and aminotriol therefore probably have a mixed origin, and most likely do not primarily represent methanotrophs here. This is in line with a low abundance of Methylocella-like methanotrophs in Sphagnum moss inferred from low or absent PCR product when using PCR primers targeting known Methylocella genes (Kip et al., 2010).

The high aminotetrol and aminopentol concentration in the shallow part of the core suggest relatively high present day methanotrophic activity compared with the lower concentration observed downcore. Alternatively, the overall downcore decrease in aminopentol and aminotetrol could be the result of on-going diagenetic decay as the zone of active production by methanotrophs is limited to the oxic (i.e. upper) part of the record.

\subsection{Hopenes as markers for methanotrophs}

Diploptene concentration generally decreases with depth while, the concentration of hop-17(21)-ene increases (Fig. 2f, g). The steady decrease in diploptene suggests that little to none is produced at depth. The decrease in diploptene and the concurrent increase in hop-17(21)-ene may reflect isomerisation of diploptene to hop-17(21)-ene. This could not, unfortunately, be confirmed from the $\delta^{13} \mathrm{C}$ values of hop-17(21)-ene, since hop-17(21)-ene co-elutes with a 2-methyl analogue, making it difficult to accurately assess its $\delta^{13} \mathrm{C}$ values. In an experiment where ${ }^{13} \mathrm{C}$ labelled methane was added to incubated Sphagnum moss, hop-17(21)-ene concentration was higher than diploptene concentration (van Winden et al., 2010). Both hopenes were strongly labelled and were therefore considered of (partial) methanotrophic origin. In a follow up field experiment using ${ }^{13} \mathrm{C}$-labelled methane, diploptene concentration was relatively high and showed strong label incorporation, while hop-17(21)-ene was below detection limit (van Winden et al., unpublished data). Furthermore, pure cultures of isolated methanotrophs contained diploptene, but no hop-17(21)-ene (van Winden et al., unpublished data). It is likely that hop17(21)-ene can be indirectly derived from methanotrophs through isomerisation of diploptene. Isomerisation of hopanoids probably occurs rapidly because of the acidic environment (cf. Pancost et al., 2003). The peak in hop-17(21)-ene abundance at $64 \mathrm{~cm}$, superimposed on the gradual increase, is not reflected in the diploptene profile and must therefore reflect another (unknown) origin.

Compound-specific $\delta^{13} \mathrm{C}$ values of diploptene vary between $-29 \%$ and $-34 \%$ (Fig. $2 \mathrm{~h}$ ). These values are relatively heavy vs. $\delta^{13} \mathrm{C}$ values observed for hopenes from Sphagnum from a field study (between ca. $-32 \%$ and $-36 \%$ ) or from a mesocosm experiment (between ca. -34 and $-41 \%$ ) (van Winden et al., 2010; unpublished data). Since $\delta^{13} \mathrm{C}$ values have been shown to correlate to methanotrophic activity, with lower values associated with higher methanotrophic activity (van Winden et al., unpublished data), the overall relatively high $\delta^{13} \mathrm{C}$ values here may suggest relatively low methane oxidation rate. Alternatively, the methanotrophic signal may be diluted by other diploptene-producing bacteria compared to fresh Sphagnum.

Diploptene ${ }^{13} \mathrm{C}$ content is relatively depleted in the lowermost samples, subsequently shifting towards higher $\delta^{13} \mathrm{C}$ values at $94 \mathrm{~cm}$ and returning towards lower $\delta^{13} \mathrm{C}$ values around $70 \mathrm{~cm}$ (Fig. 2h). Above this depth, the ${ }^{13} \mathrm{C}$ content of diploptene remains low, only returning to higher values around $14 \mathrm{~cm}$. At the top part of the profile, between 20 and $45 \mathrm{~cm}$, diploptene $\delta^{13} \mathrm{C}$ values are relatively low, in line with a high abundance of aminotetrol and aminopentol, thereby reflecting the currently active methanotrophic community (Fig. 2d, e and h). In the topmost samples, around $14 \mathrm{~cm}$, diploptene is relatively high in ${ }^{13} \mathrm{C}$, corresponding to low aminotetrol and aminopentol concentrations, in line with low methanotrophic activity above the oxic-anoxic interface .

The diploptene ${ }^{13} \mathrm{C}$ content in the deeper parts of the peat is high vs. recent values. Also, aminopentol and aminotetrol suggest relatively high present day methanotrophic activity, with relatively high abundances vs. the lower concentrations downcore. This can be explained in several ways. First, it could indicate that present-day methanotrophic activity is relatively high vs. past activity. Second, it could be the result of (enhanced) contribution of relatively ${ }^{13} \mathrm{C}$ enriched diploptene originating from a different bacterial source in the deeper - anoxic - part of the profile. Hopanoids have been found in anaerobic bacteria (Sinninghe Damsté et al., 2004; Fischer et al., 2005; Blumenberg et al., 2006) and diploptene is, for example, a major neutral lipid of anammox bacteria (Sinninghe Damsté et al., 2005). However, diploptene concentration indicates little to no diploptene production at depth. Third, the overall downcore decrease in aminopentol and aminotetrol could be a result of on going decay as the zone of active production by methanotrophs is limited to the oxic (i.e. upper) part of the record.

\subsection{Potential relationship between extent of methane cycling and water level}

Over time, methanotrophic activity may have co-varied with water level or temperature. In the Misten Bog profile, two wet phases were recognised, marked by a shift in vegetation towards Sphagnum section Cuspidata (S. s. Cuspidata), which is restricted to wet bog surface conditions (Fig. 2; De Vleeschouwer et al., 2012). These wet phases occurred around the 8th-9th and around the 13th century AD (De Vleeschouwer et al., 2012). These periods are governed by high relative water level, the result of the balance between precipitation and evaporation. Field studies and laboratory experiments have revealed increasing methanotrophic activity with increasing water level (Basiliko et al., 2004; Raghoebarsing et al., 2005; Kip et al., 2010; Larmola et al., 2010).

Indeed, aminotetrol shows elevated values coinciding with the wet phases; however, aminopentol and diploptene $\delta^{13} \mathrm{C}$ values do not show this (Fig. 2). Therefore, no clear conclusions can be drawn from the combination of different methanotroph biomarkers.

A reason for the discrepancy between the methanotroph markers is possibly the predominance of type II methanotrophs. They use a combination of available $\mathrm{CH}_{4}$ and $\mathrm{CO}_{2}$, potentially leading to a dispersed $\delta^{13} \mathrm{C}$ signature. Additionally, the diploptene $\delta^{13} \mathrm{C}$ values may be derived from a combination of sources, masking a possible methanotrophic activity related profile. Furthermore, type II methanotrophs do not produce aminopentol, which explains why the aminopentol concentration, close to the detection limit, does not show a clear trend with depth.

Alternatively, the climatic shifts during the formation of the peat bog may have been insufficient to cause significant variation in the methanotroph proxies, explaining the lack of consistency between the proxies. The peaks in aminotetrol may be coincidental, or caused by other bacteria also producing aminotetrol, for instance sulfate reducing bacteria (cf. Blumenberg et al., 2006, 2009a,b), although unlikely in a sulfate-poor environment, or unknown species.

In order to establish how methanotrophic activity correlates with climatic changes, a future study could combine a study of methanotroph biomarkers with additional proxies which may provide information on water level and the methane cycle, such 
as testate amoebae, macrofossils and archaeol (cf. Woodland et al., 1998; Pancost et al., 2011). Finally, to ensure sufficient variation in the methanotroph proxies, future research should focus on peat deposits reflecting larger shifts in climate.

\section{Conclusions}

Relatively high methanotrophic activity was recorded by the investigated methanotrophic markers between 20 and $45 \mathrm{~cm}$, around the present oxic-anoxic boundary, most likely representing a currently active methanotrophic community. A predominance of aminotetrol over aminopentol indicated a prevalence of type II methanotrophs. In the deeper parts of the peat, methanotrophic markers did not show a clear correlation between the past change in water level and methanotrophic activity. This may be related to a predominance of type II methanotrophs, which do not produce aminopentol and which consume both $\mathrm{CO}_{2}$ and $\mathrm{CH}_{4}$, resulting in a lower sensitivity of diploptene $\delta^{13} \mathrm{C}$ values, Furthermore, the lack of correlation could be caused by a mixture of sources for the biomarkers or insufficient variation in climatic change. A proposed way forward would include a study of peat deposits, showing greater climatic variability, with the application of multiple proxies.

\section{Acknowledgements}

We thank M. Kienhuis and S. Schouten, NIOZ Texel, for technical assistance with GC-IRMS. The Darwin Center for Biogeosciences partially funded the project via a grant to J.S.S.D. We thank The Science Research Infrastructure Fund (SRIF) from HEFCE for providing funding (to H.M.T.) for purchase of a ThermoFinnigan LCQ ion trap mass spectrometer. W. Shotyk (University of Heidelberg) is thanked for the loan of a Wardenaar corer and for allowing use of the peat-cutting facilities at the IES (University of Heidelberg, Germany). M. Mathijs and M. Court-Picon were of great help in the field. P. Mertes (DNF-Belgian Forest and Nature Ministry) is also acknowledged for providing authorization for coring the Misten bog. We thank R.D. Pancost and an anonymous reviewer for constructive comments which helped to improve the manuscript.

\section{Guest associate Editor - T. Wagner}

\section{References}

Appleby, P.G., 2001. Chronostratigraphic techniques in recent sediments. In: Last, W.M., Smol, J.P. (Eds.), Tracking Environmental Change Using Lake Sediments, Basin Analysis, Coring and Chronological Techniques, vol. 1. Springer, pp. 171203.

Basiliko, N., Knowles, R., Moore, T.R., 2004. Roles of moss species and habitat in methane oxidation in a northern peatland. Wetlands 24, 178-185.

Blumenberg, M., Krüger, M., Nauhaus, K., Talbot, H.M., Oppermann, B.I., Seifert, R. Pape, T., Michaelis, W., 2006. Biosynthesis of hopanoids by sulfate-reducing bacteria (genus Desulfovibrio). Environmental Microbiology 8, 1220-1227.

Blumenberg, M., Seifert, R., Kasten, S., Bahlmann, E., Michaelis, W., 2009a. Euphotic zone bacterioplankton sources major sedimentary bacteriohopanepolyols in the Holocene Black Sea. Geochimica et Cosmochimica Acta 73, 750-766.

Blumenberg, M., Oppermann, B.I., Guyoneaud, R., Michaelis, W., 2009b. Hopanoid production by Desulfovibrio bastinii isolated from oilfield formation water. FEMS Microbiology Letters 293, 73-78.

Cooke, M.P., Talbot, H.M., Farrimond, P., 2008. Bacterial populations recorded in bacteriohopanepolyol distributions in soils from Northern England. Organic Geochemistry 39, 1347-1350.

Cooke, M.P., 2010. The Role of Bacteriohopanepolyols as Biomarkers for Soil Bacterial Communities and Soil Derived Organic Matter. PhD Thesis. Newcastle University, UK.

Coolen, M.J.L., Talbot, H.M., Abbas, B.A., Ward, C., Schouten, S., Volkman, J.K. Sinninghe Damsté, J.S., 2008. Sources for sedimentary bacteriohopanepolyols as revealed by $16 \mathrm{~S}$ rDNA stratigraphy. Environmental Microbiology 10, 17831803

Cvejic, J.H., Bodrossy, L., Kovács, K.L., Rohmer, M., 2000. Bacterial triterpenoids of the hopane series from the methanotrophic, bacteria Methylocaldum spp.: phylogenetic implications and first evidence for an unsaturated aminobacteriohopanepolyol. FEMS Microbiology Letters 182, 361-365.

Crossman, Z.M., Abraham, F., Evershed, R.P., 2004. Stable isotope pulse-chasing and compound-specific stable carbon isotope analysis to assess methane oxidising bacterial populations in landfill cover soil. Environmental Science and Technology 38, 1359-1367.

De Vleeschouwer, F., Pazdur, A., Luthers, C., Streel, M., Mauquoy, D., Wastiaux, C., Le Roux, G., Moschen, R., Blaauw, M., Pawlyta, J., Sikorski, J., and Piotrowska, N., in press. A millennial record of environmental change in peat deposits from the Misten bog (East Belgium). Quaternary International. http://dx.doi.org/10.1016/ j.quaint.2011.12.010.

Dedysh, S.N., 2009. Exploring methanotroph diversity in acidic northern wetlands: Molecular and cultivation-based studies. Microbiology 78, 655-669.

Fischer, W.W., Summons, R.E., Pearson, A.P., 2005. Targeted genomic detection of biosynthetic pathways: anaerobic production of hopanoid biomarkers by a common sedimentary microbe. Geobiology 3, 33-40.

Frenzel, P., Karofeld, E., 2000. $\mathrm{CH}_{4}$ emission from a hollow-ridge complex in a raised bog: the role of $\mathrm{CH}_{4}$ production and oxidation. Biogeochemistry 51, 91112.

Gorham, E., 1991. Northern peatlands: role in the carbon balance and probable responses to climatic warming. Ecological Applications 1, 182-195.

Kip, N., van Winden, J.F., Pan, Y., Bodrossy, L., Reichart, G.J., Smolders, A.J.P., Jetten, M.S.M., Sinninghe Damsté, J.S., Op den Camp, H.J.M., 2010. Global prevalence of methane oxidation by symbiotic bacteria in peat moss ecosystems. Nature Geoscience 3, 617-621.

Kip, N., Dulith, B.E., Pan, Y., Bodrossy, L., Neveling, K., Kwint, M.P., Jetten, M.S.M., Op den Camp, H.J.M., 2011. Ultra-deep pyrosequencing of pmoA amplicons confirms the prevalence of Methylomonas and Methylocystis in Sphagnum mosses from a Dutch peat bog. Environmental Microbiology Reports. http:// dx.doi.org/10.1111/j.1758-2229.2011.00260.x.

Larmola, T., Tuittila, E.-S., Tiirola, M., Nykänen, H., Martikainen, P.J., Yrjälä, K., Tuomivirta, T., Fritze, H., 2010. The role of Sphagnum mosses in the methane cycling of a boreal mire. Ecology 91, 2356-2365.

McNamara, N.P., Plant, T., Oakley, S., Wood, C., Ostle, N., 2008. Gully hotspot contribution to landscape methane $\left(\mathrm{CH}_{4}\right)$ and carbon dioxide $\left(\mathrm{CO}_{2}\right)$ fluxes in a northern peatland. Science of the Total Environment 404, 354-360.

Neunlist, S., Rohmer, M., 1985a. Novel hopanoids from the methylotrophic bacteria Methylococcus capsulatus and Methylomonas methanica (22S)-35-amino bacteriohopane-30,31,32,33,34-pentol and (22S)-35-amino-3b-methylbacter iohopane-30,31,32,33,34-pentol. Biochemical Journal 231, 635-639.

Neunlist, S., Rohmer, M., 1985b. The hopanoids of 'Methylosinus trichosporium': aminobacteriohopanetriol and aminobacteriohopanetetrol. Journal of General Microbiology 131, 1363-1367.

Pancost, R.D., Baas, M., van Geel, B., Sinninghe Damsté, J.S. 2003. Response of an ombrotrophic bog to a regional climate event revealed by macrofossil, molecular and carbon isotopic data. The Holocene 13, 921-932.

Pancost, R.D., McClymont, E.L., Bingham, E.M., Roberts, Z., Charman, D.J. Hornibrook, E.R.C., Blundell, A., Chambers, F.M., Lim, K.L.H., Evershed, R.P., 2011. Archaeol as a methanogen biomarker in ombrotrophic bogs. Organic Geochemistry 42, 1279-1287.

Raghoebarsing, A.A., Smolders, A.J.P., Schmid, M.C., Rijpstra, W.I.C., Wolters-Arts, M., Derksen, J., Jetten, M.S.M., Schouten, S., Sinninghe, Jaap.S., Damsté, J.S., Lamers, L.P.M., Roelofs, J.G.M., Op den Camp, H.J.M., Strous, M., 2005. Methanotrophic symbionts provide carbon for photosynthesis in peat bogs. Nature 436, 1153 1156.

Reimer, P.J., Baillie, M.G.L., Bard, E., Bayliss, A., Beck, J.W., Blackwell, P.G., Bronk Ramsey, C., Buck, C.E., Burr, G., Edwards, R.L., Friedrich, M., Grootes, P.M., Guilderson, T.P., Hajdas, I., Heaton, T.J., Hogg, A.G., Hughen, K.A., Kaiser, K.F., Kromer, B., McCormac, F.G. Manning S., Reimer, R.W Richards, D.A., Southon, J.R., Talamo, S., Turney, C.S.M., van der Plicht, J., Weyhenmeyer, C.E., 2009. IntCal09 and Marine09 radiocarbon age calibration curves, 0-50,000 years cal BP. Radiocarbon 51, 1111-1150.

Rohmer, M., Bouvier-Nave, P., Ourisson, G., 1984. Distribution of hopanoid triterpenes in prokaryotes. Journal of General Microbiology 130, 1137-1150.

Sinninghe Damsté, J.S., Rijpstra, W.I.C., Schouten, S., Fuerst, J.A., Jetten, M.S.M., Strous, M., 2004. The occurrence of hopanoids in planctomycetes: Implications for the sedimentary biomarker record. Organic Geochemistry 35, 561-566.

Sinninghe Damsté, J.S., Rijpstra, W.I.C., Geenevasen, J.A.J., Strous, M., Jetten, M.S.M., 2005. Structural identification of ladderane and other membrane lipids of planktomycetes capable of anaerobic ammonium oxidation (anammox). FEBS Journal 272, 4270-4283.

Smith, L.C., MacDonald, G.M., Velichko, A.A., Beilman, D.W., Borisova, O.K., Frey, K.E., Kremenetski, K.V., Sheng, Y., 2004. Siberian peatlands a net carbon sink and global methane source since the early Holocene. Science 303, 353-356.

Talbot, H.M., Watson, D.F., Murell, J.C., Carter, J.F., Farrimond, P., 2001. Analysis of intact bacteriohopanepolyols from methanotrophic bacteria by reversed-phase high performance liquid chromatography-atmospheric pressure chemical ionisation mass spectrometry. Journal of Chromatography A 921, 175185.

Talbot, H.M., Summons, R.E., Jahnke, L.L., Cockell, C.S., Rohmer, M., Farrimond, P., 2008. Cyanobacterial bacteriohopanepolyol signatures from cultures and natural environmental settings. Organic Geochemistry 39, 232-263.

Wardenaar, E.P.C., 1986. A new hand tool for cutting peat profiles. Canadian Journal of Botany 65, 1772-1773. 
van Winden, J.F., Kip, N., Reichart, G.J., Jetten, M.S.M., Op den Camp, H.J.M., Sinninghe Damsté, J.S., 2010. Lipids of symbiotic methane-oxidizing bacteria in peat moss studied using stable carbon isotopic labelling. Organic Geochemistry $41,1040-1044$.

van Winden, J.F., Reichart, G.J., McNamara, N.P., Benthien, A., Sinninghe Damsté, J.S., 2012a. Temperature-induced increase in methane release from peat bogs. PLoS one 7 (6): e39614. http://dx.doi.org/10.1371/journal.pone.0039614. van Winden, J.F., Talbot, H.M., Kip, N., Reichart, G.J., Pol, A., McNamara, N.P., Jetten, M.S.M., Op den Camp, H.J.M., Sinninghe Damsté, J.S., 2012 b. Bacteriohopanepolyol signatures as markers for methanotrophic bacteria in peat moss. Geochimica et Cosmochimica Acta 77, 52-61.

Woodland, W.A., Charman, D.J., Sims, P.C., 1998. Quantitative dominated estimates of water tables and soil moisture in Holocene peatlands from testate amoebae. Holocene 8, 261-273. 